\title{
A STUDY ABOUT TEST PERFORMANCES OF RIO DE JANEIRO COUNTY STUDENTS IN 2012 AND 2011 BASED ON LONGITUDINAL DATA
}

\author{
Leandro Lins Marino ${ }^{1}$, Denise Britz do Nascimento Silva ${ }^{2}$ and Ruben Klein ${ }^{1}$ \\ ${ }^{1}$ Cesgranrio Foundation, Brazil \\ ${ }^{2}$ National School of Statistical Sciences, Brazil \\ leandromarino@leandromarino.com.br
}

The aim of this paper is to identify school, parents' and students' characteristics associated with educational achievement of students in the third, fourth, seventh and eighth years measured by a large assessment test. We analyze individual and school level factors that can affect the student achievement and, in addition, the work looks for factors influencing performance gains between two consecutive evaluation rounds. The analysis is conducted based on a two-level hierarchical linear model. The primary data source was an educational assessment procedure conducted by Rio de Janeiro City Council. The results confirm some findings already obtained in cross-sectional studies. Furthermore, these findings show a main effect associated with the fail/pass event in $3 r d$ grade students and that not only low-performance students may fail the final exams and have been held back in school.

\section{INTRODUCTION}

The advent of large-scale educational assessments, in mid-twentieth century, made new studies emerge in the educational field. Among these studies, one of the most prominent and important is the Coleman Report (Bonamino \& Franco, 1999), prepared based on information from a quantitative research on a sample of approximately six hundred and fifty thousand American students. The objective of this research was to investigate the association among variables linked to socio-economic background and student performance, in order to support public policies for school improvement.

In Brazil, the introduction of a large-scale national educational assessment, known as Basic Education Evaluation System (SAEB), in 1995 led to great opportunities and advances for the investigation of factors that may be related to student achievement (Andrade \& Laros, 2007; Ferrão et al., 2001). One example of the findings is presented on the SAEB 1999 Report (Instituto Nacional de Pesquisas Educacionais Anísio Teixeira [INEP], 2000) that provides evidence regarding the impact that the education gap has on student performance.

The availability of large-scale assessment results together with an information system about students, parents, teachers and schools characteristics opened new avenues in educational research. In particular, those related to the investigation of factors that could be associated with student performance. In particular, it is now possible to conduct longitudinal data analysis if a cohort of students takes part on periodic assessments across the years. The longitudinal analysis is usually based on a set of units (a panel) that are measured repeatedly at different occasions.

\section{MOTIVATION AND GOALS}

Although there are cases of longitudinal educational studies in Brazil, cross-sectional studies are much more common. One of the main reasons for that is a known deficiency in the available educational databases making hard to track a student trajectory along the years. In addition, a high number of State assessment systems do not perform longitudinal evaluations. Rio de Janeiro City Council carries out an evaluation designed to assess students in two consecutive periods. The evaluation, called Prova Rio (Prova means exam or test in Portuguese), is held annually and assesses public school students that are in the $3^{\text {rd }}, 4^{\text {th }}, 7^{\text {th }}$ or $8^{\text {th }}$ grades of Basic Education. This assessment is mandatory therefore all students of these grades are required to undertake the exams.

This paper investigates which students', parents' and schools' characteristics are associated with student performance measured by Prova Rio in 2011 and 2012. We analyze student features and characteristics of educational institutions that may influence the performance of children and young participants of Prova Rio in 2011 and 2012. The overall objective is to portray those factors associated with student proficiency and their educational institutions that were engaged on this

In: M.A. Sorto (Ed.), Advances in statistics education: developments, experiences and assessments. Proceedings of the Satellite conference of the International Association for Statistical Education (IASE), July 2015, Rio de Janeiro, Brazil. 
evaluation process in 2011 as well as in 2012. The target population in this study is comprised of students who were registered in the $3^{\text {rd }}$ and $7^{\text {th }}$ grades in 2011 and also participated in the 2012 follow-up assessment even if they have failed the finals exams in 2011. It also stands out as a specific objective of this work the investigation of students' and schools' characteristics that are associated with the gain in performance, measured by Prova Rio between two consecutive years.

To achieve the proposed goals, we employ a hierarchical model with two levels, one for students and another for schools. As data sources we use City Council student databases containing Prova Rio results (proficiency scores) plus socioeconomic and cultural features of students and school characteristics obtained from Prova Rio and also complementary information regarding the schools collected by Prova Brasil which, in turn, is a nationwide voluntary proficiency test for public school students in the $4^{\text {th }}$ and $8^{\text {th }}$ grades conducted by the Instituto Nacional de Estudos $e$ Pesquisas Educacionais Anísio Teixeira of the Brazilian Ministry of Education.

\section{DATA CHARACTERIZATION}

The Prova Rio assessment is a test applied by Rio de Janeiro City Council since 2009 and whose results are used as an input to produce an Educational Development Index for the city (IDERio). Furthermore, this examination is used in the accountability process for rewarding teachers and school employees. Figure 1 displays the longitudinal characterization of this study.

2011

Grades evaluated

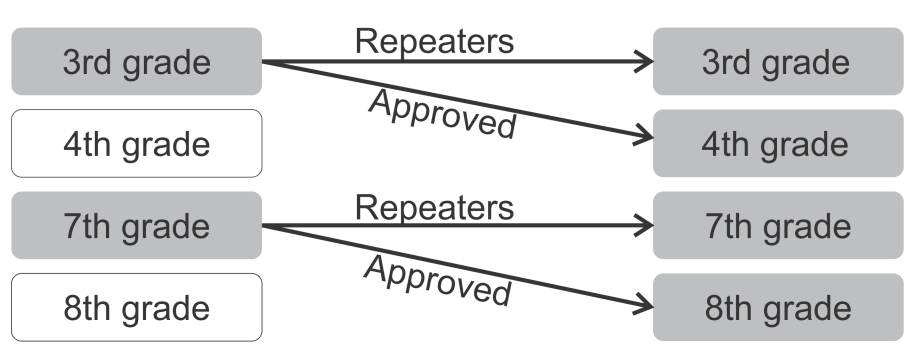

2012

Grades evaluated

Figure 1. Longitudinal Characterization

Prova Rio evaluation process also collects information regarding students' and teachers' backgrounds, as socioeconomic and cultural features of students and their families, gathers information about the dynamics that takes place in classrooms between teachers and students, and also about structural features of schools. The student questionnaire contains, among others, questions related to their attitudes towards activities proposed by teachers, parental engagement and encouragement, behavior of classmates etc. However, the student questionnaire, does not collect any information regarding the student socioeconomic level. To bypass this situation, we use a proxy measure collected by Prova Brasil at the school level. We consider exploiting Prova Brasil to obtain supplementary information on schools since student records from Prova Rio and Prova Brasil cannot be matched, record linkage between this two databases is only possible at the school level.

Prova Rio evaluates annually almost fifty thousand students in each grade. Although the assessment system is designed to evaluate the same student on different occasions, it is hard to track a student in the database. Table 1 presents the number of schools and students, as well as, the mean proficiency of each subgroup of students.

Table 1.

Number of schools, students and proficiency mean by year and grade - Rio de Janeiro, 2011-2012

\begin{tabular}{|c|c|c|c|c|c|}
\hline Year & Grade & Area & Schools & Students & Proficiency \\
\hline \multirow{4}{*}{2011} & \multirow{2}{*}{$3^{\text {rd }}$ grade } & Math & 577 & 29,857 & 162.5 \\
\hline & & Read & 577 & 29,847 & 160.9 \\
\hline & \multirow{2}{*}{$7^{\text {th }}$ grade } & Math & 343 & 29,821 & 225.2 \\
\hline & & Read & 343 & 29,815 & 224.7 \\
\hline 2012 & $3^{\text {rd }}$ grade & Math & 448 & 2,339 & 146.6 \\
\hline
\end{tabular}




\begin{tabular}{ccccc} 
Repeaters & Read & 449 & 2,334 & 138.5 \\
\hline \multirow{2}{*}{$4^{\text {th }}$ grade } & Math & 596 & 27,518 & 189.1 \\
& Read & 596 & 27,513 & 193.5 \\
\hline $7^{\text {th }}$ grade & Math & 309 & 2,369 & 205.3 \\
Repeaters & Read & 309 & 2,364 & 207.6 \\
\hline \multirow{2}{*}{$8^{\text {th }}$ grade } & Math & 338 & 27,452 & 238.6 \\
& Read & 338 & 27,451 & 233.8
\end{tabular}

Source: Prova Rio 2011 and Prova Rio 2012

Table 1 shows that even students attending the $3^{\text {rd }}$ grade for the second time has lower performance score when compared with the entire group of students attending $3^{\text {rd }}$ grade in 2011 . The same happens with $7^{\text {th }}$ grade students. Furthermore, it can be noted that the retention rate between $3^{\text {rd }}$ to $4^{\text {th }}$ grade, and $7^{\text {th }}$ to $8^{\text {th, }}$ grade is close to $10 \%$.

\section{METHODOLOGY}

The longitudinal analysis is characterized by the observation of the same individual, or a set of individuals, repeatedly over time allowing the study of change. Longitudinal data are collected in a time sequence that clarifies the direction as well as the magnitude of change among variables (Menard 1991). In a longitudinal study it is possible to characterize the evolution of a phenomenon in a particular subpopulation over time at the individual level. In successive crosssectional studies, one can only measure average variations between populations. For example, students with lower socioeconomic status tend to obtain lower performance scores when compared to those with more advantageous socioeconomic situation. A longitudinal study permits the investigation on how (or if) the educational system is operating to reduce the distance between performance levels of students from different socioeconomic groups. In this study, we employ a kind of Value-Added Model (VAM). McCaffrey, Koretz, Louis \& Hamilton (2004) points out a belief that with this approach can remove the effects of factors not under the control of the school and "thereby provides a more accurate indicator of school or teacher effectiveness than is possible when these factors are not controlled" (p.68).

Prova Rio is designed to assess students in two consecutive occasions $\left(3^{\text {rd }}\right.$ and $4^{\text {th }}$ grades; $7^{\text {th }}$ and $8^{\text {th }}$ grades) but there is no data available from students that have already been evaluated on all 4 grades. So, for each student we only have two occurrences (test results on $3^{\text {rd }}$ and $4^{\text {th }}$ grades or test results on $7^{\text {th }}$ and $8^{\text {th }}$ grades).. Therefore, we model student performance scores in 2012 as the dependent variable and the score in 2011 as an independent variable, in order to make use of the longitudinal aspect of the data and control for the student's prior performance. In addition, we modelled the gain in proficiency between 2012 and 2011. Both models are presented below and are defined as a hierarchical multilevel model with two levels (student and school).

$$
\begin{gathered}
Y_{i j}^{(1)}=\alpha_{j}+\beta_{0} Y_{i j}^{(0)}+\sum_{\{k=1\}}^{K} \beta_{k} X_{i j k}+\epsilon_{i j}, \quad \alpha_{j}=\gamma_{00}+\sum_{M} \zeta_{m} X_{0 j m}+u_{j} \\
u_{j} \sim N\left(0, \sigma_{u}^{2}\right) ; \quad \epsilon_{i j} \sim N\left(0, \sigma_{\epsilon}^{2}\right) ; \quad \sigma^{2}=\sigma_{u}^{2}+\sigma_{\epsilon}^{2}
\end{gathered}
$$

For the gain model consider $G_{i j}=Y_{i j}^{(1)}-Y_{i j}^{(0)}$ the gain and the main model equation is then defined as: $G_{i j}=\alpha_{j}+\sum_{\{k=1\}}^{K} \beta_{k} X_{i j k}+\epsilon_{i j}$

where, $Y_{i j}^{(1)}$ is the proficiency of student $i$ from school $j$ in 2012; $Y_{i j}^{(0)}$ is the proficiency of student $i$ from school $j$ in 2011; $\beta_{0}$ is the linear coefficient for the 2011 score; $\beta_{k}$ the student level coefficient; $X_{i j k}$ is the value for the auxiliary variable $k$ for student $i$ in school $j$; $\zeta_{m}$ is the school level coefficient; $X_{0 j m}$ is the value for variable $m$ from school $j ; \epsilon_{i j}$ is the student level error that is normal distributed with mean 0 and variance $\sigma_{\epsilon}^{2} ; u_{j}$ the error term for school and also assumed to be normal distributed with mean 0 and variance $\sigma_{u}^{2} ; \sigma^{2}$ is the total variance that can be decomposed in school and student level. The estimation process is conduct using the Full 
Maximum Likelihood approach. We also consider some criteria to select the adequate model, such as likelihood ratio statistics, Akaike Information Criterion and Bayesian Information Criterion.

\section{RESULTS}

Although socioeconomic level (SEL) constitutes an important characteristic associated with student achievement, as pointed out before, Prova Rio student questionnaire does not collect any information regarding SEL neither collects data about ownership of assets like computers, televisions, commonly used to estimate household socioeconomic level in Brazil.

The Table 2 presents the estimated coefficients for all fitted the models. Interactions between some variables were tested but none of them was significant. Model results provide evidence that male students have lower performance when compared to female students in Read, when controlling for the different student and school effects. On the other hand, for Reading test the opposite occurs.

Table 2.

Estimated coefficients in two-level hierarchical models

\begin{tabular}{|c|c|c|c|c|c|}
\hline \multirow{2}{*}{ Variable } & \multicolumn{2}{|c|}{$3^{\text {rd }} / 4^{\text {th }}$ grades } & \multicolumn{2}{|c|}{$7^{\text {th }} / 8^{\text {th }}$ grades } & \multirow{2}{*}{$\frac{3^{\text {rd }} / 4^{\text {th }} \text { grades }}{\text { Gain }}$} \\
\hline & Read & Math & Read & Math & \\
\hline \multicolumn{6}{|l|}{ Level: Student } \\
\hline Intercept & 57.936 & 61.147 & 87.033 & 96.154 & 24.306 \\
\hline 2011 proficiency & 0.564 & 0.523 & 0.610 & 0.503 & - \\
\hline Sex (male) & -4.180 & 3.849 & -7.529 & 3.009 & -1.330 \\
\hline Race or skin colour (pardo, brown) & -3.766 & -3.830 & -2.611 & -2.762 & - \\
\hline Race or skin colour (black) & -5.928 & -7.867 & -3.385 & -4.816 & - \\
\hline $\begin{array}{l}\text { Student has been promoted to the } 4^{\text {th }} \\
\text { or } 8^{\text {th }} \text { grade after approval on } 3^{\text {rd }} \text { or } \\
7^{\text {th }} \text { grade }\end{array}$ & 25.646 & 16.878 & 2.623 & 15.963 & 6.624 \\
\hline $\begin{array}{l}\text { Schooling/grade delay measured in } \\
\text { years (effect centered at school level l) }\end{array}$ & -3.608 & -3.145 & -4.740 & -4.726 & -2.221 \\
\hline Parental encouragement level $=1$ & 3.455 & 3.158 & 2.790 & $1.572 *$ & $0.215^{* *}$ \\
\hline Parental encouragement level $=2$ & 7.139 & 5.906 & 3.288 & 2.906 & $1.933^{*}$ \\
\hline \multicolumn{6}{|l|}{ Level: School } \\
\hline Average schooling gap (delay) & -8.362 & $-6.303 *$ & 10.169 & -8.442 & -3.974 \\
\hline Average socioeconomic index & 1.374 & 1.535 & 1.185 & 1.187 & - \\
\hline Building condition index & $0.878^{*}$ & $1.112^{*}$ & - & - & - \\
\hline Illumination index & $1.210^{*}$ & $1.604^{*}$ & - & - & - \\
\hline School demand indicator & - & - & 3.613 & $3.832 *$ & - \\
\hline Nonviolent environment index & - & - & - & 0.983 & - \\
\hline
\end{tabular}

Note. ${ }^{* *}$ not significant; ${ }^{*}$ p-value $<0.05$; all other are significant at $.001 ; 3^{\text {rd }}$ grade gain model was conduct only for reading exam

Source: Prova Rio 2011, Prova Rio 2012 and Prova Brasil 2011

- Parental encouragement level: An index that represent the strength of parental encouragement related to school activities and student commitment (parents stimulate the students to go to school, to do their homework and to read books, parents celebrate the student's achievements). The higher the value, more pro-education parents are. The baseline line level refers to parents who do not provide any incentive to the student.

- Building condition index: Is a proxy measure of the school facility condition. Is composed of 13 items related to the building condition and repairs needed, for example, in toilets, school kitchen, doors, windows, classrooms, the roof and etc. A higher value indicate that the school building is in good condition. 
- Illumination index: Is a proxy measure obtained from a qualitative evaluation related to lighting and ventilation condition of school classrooms. A higher value indicates a better condition.

- School demand indicator: Indicates if enrolment demand is higher than the number of vacancies in the school resulting in a high number of applicants per vacancy.

- Nonviolent environment index: Is calculated taking into account 35 items related to violent actions or behaviour that could have happened in the school. The measure is defined such that low value indicates some occurrence of violent incidents. The index is defined with values 0,1 , 2 and 3, The latter indicates no violent event took place in the school in the academic year.

As shown in Table 2, there is evidence that race is an important factor associated with student achievement. Therefore, in the case of this Brazilian study, even when the model controls for several student characteristics, race/skin color effect is still related to achievement gap. However, it is essential to notice that the fitted models do not take into account any socioeconomic variable in the student level and it is known that, in Brazil, there is evidence that race is strongly correlated with SEL. Model results indicate that pardo/brown students have lower performance score when compared to white pupils and, in turn, black pupils show a worse achievement when compared to the browns. It is important to highlight that the race/skin color effect was not significant for the $3^{\text {rd }}$ grade gain model on Reading. Therefore, one may conclude that the existing differentials between white/brown and white/black pupils do not increase between two consecutive years. In respect to the estimated coefficients, we can observe a lower impact of the skin color effect in the $7^{\text {th }}$ grade model.

In addition, schooling delay stands a significant factor in all proposed models. This shows that much care is need to support delayed students, providing favorable conditions to allow them to overcome the difficulties. Unfortunately, grade retention should not be something common in schools, however, this study shows a large quantity of students facing grade repetition. The results demonstrate that promoted students has a huge increase in proficiency when compared with repeaters as presented in Table 2. For example, considering the model for Reading $-3^{\text {rd }} / 4^{\text {th }}$ grades, students who were promoted from the $3^{\text {rd }}$ to the $4^{\text {th }}$ grade have on average a performance score 25 points higher those enrolled in the $4^{\text {th }}$ grade for the second time. Table 1 outcomes corroborate this fact since repeaters show an average performance lower than the average performance of all students in 2011.

The presence of parents or guardians in the student's everyday life has a positive effect on achievement as estimated by the parental encouragement indicator. In this study we notice a smaller school-effect when compared to other Brazilian educational multilevel modelling studies. Many others studies shows school-effects higher than those obtained here. Ferrão et al. (2001) points that the extent of school-effect found in international studies is between $8 \%$ and $18 \%$ and we get values between $2.4 \%$ and $5 \%$.

\section{CONCLUSIONS}

This paper investigates factors that are usually associated with student proficiency. A special note goes for the issue of grade repetition since the study provides evidence that the students who promote have a higher performance score than those who are enrolled on same grade for a second time. Besides that, the exploratory data analysis also shows that repeaters have on average lower score in 2012 even when compared with all the target population in the same grade in 2011 or 2012.

The case of how to deal with repeaters and the grade retention process has to be analyzed carefully not only because of the financial cost of repetition but also for the consequences on the pupil educational development and well-being. In a public educational system, the repetition cost is shared between all county citizens. Therefore, it is vital to focus on what are the in-year factors that are associated with such a high grade retention grade ( one in every ten students faces grade repetition in the grades in the scope of this study). A deeper understanding of intra-class and intraschool factors are in need.

It is noticeable that the support from parents and guardians, encouraging the students to be committed with doing their homework, with reading, with school attendance and talking with them 
about the school life are associated with better performance. This, in particular, may be discussed with parents and guardians in school meetings. In modern society, some delegate this care related to the student learning process only to the educational institutions. This attitude has not been proven effective on student achievement.

Lastly, another factor positively associated with student proficiency is the school environment. Schools with good lighting conditions, airy classrooms, those without violent incidents in their daily routine, are vital to offer the students the expected conditions as a learning environment. The students need a well organized and pleasant environment to appropriately develop their abilities.

\section{REFERENCES}

Bonamino, A., \& Franco, C. (1999). Educational policy and evaluation: the process of institutionalization of the brazilian national system for the evaluation of basic education (SAEB). Cadernos de Pesquisa(108), 101-132. doi: http://dx.doi.org/10.1590/S010015741999000300005

Andrade, J. M., \& Laros. J. A. (2007). Factors associated with school performance: a multilevel study with data of SAEB/2001. Psic.: Teor. e Pesq.(23)1 33-41. doi: http://dx.doi.org/10.1590/S0102-37722007000100005.

Ferrão. M. E., Beltrão, K. I., Fernandes, C., Santos, D., Suárez, M., \& Andrade, A. C. (2001) O SAEB -Sistema Nacional de Avaliação da Educação Básica: objetivos, características e contribuições na investigação da escola eficaz. Revista Brasileira de Estudos de População, 18(1/2), 111-130. Retrieved from: http://www.abep.nepo.unicamp.br/docs/rev_inf/ vol18_n1e2_2001/vol18_n1e2_2001_7artigo_111_130.pdf

Ferrão, M. E., Beltrão, K. I., \& Santos, D. P. (2002). O impacto de políticas de não-repetência sobre o aprendizado dos alunos da $4^{\text {a }}$ série. Pesquisa e Planejamento Econômico, 32(3), $495-$ 513. Retrieved from: http://www.ppe.ipea.gov.br/index.php/ppe/article/viewFile/141/76

Ferrão, M. E., \& Fernandes, C. (2003) O efeito-escola e a mudança - dá para mudar? evidências da investigação brasileira. REICE - Revista Electrónica Iberoamericana sobre Calidad, Eficacia y Cambio en Educación, 1(1), 1-13. Retrieved from: http://www.ice.deusto.es/RINACE/reice/ vol $1 \mathrm{n} 1 /$ FerraoyFernandes.pdf

INEP. (2000). Relatório SAEB 1999 (Tech. Rep.). Braslia, DF: Ministério da Educação. Retrieved from http://download.inep.gov.br/download/saeb/1999/resultados/saeb99_relatorio.doc

McCaffrey, D. F., Lockwood, J. R., Koretz, D., Louis, T. A., \& Hamilton, L. (2004). Models for value-added modeling of teacher effects. Journal of Educational and Behavioral Statistics, 29(1), 67-101. Retrieved from http://www.rand.org/content/dam/rand/pubs/reprints/2005/ RAND_RP1165.pdf

Menard, S. (1991) Longitudinal Research, Newbury Park: Sage Publications. 